\title{
Characterization of putative pathogenic Shewanella algae isolated from ballast water
}

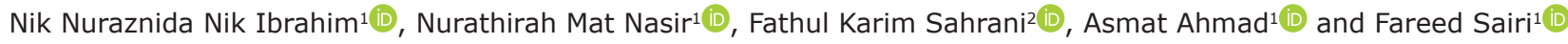 \\ 1. Department of Biological Sciences and Biotechnology, Faculty of Science and Technology, Universiti Kebangsaan \\ Malaysia, 43600 Bangi, Selangor, Malaysia; 2. Department of Earth Sciences and Environment, Faculty of Science and \\ Technology, Universiti Kebangsaan Malaysia, 43600 Bangi, Selangor, Malaysia. \\ Corresponding author: Fareed Sairi, e-mail: fareed@ukm.edu.my \\ Co-authors: NNNI: aznida_nf@yahoo.com, NMN: nur_athi90@yahoo.com, FKS: fathul@ukm.edu.my, \\ AA: drasmart@gmail.com \\ Received: 29-09-2020, Accepted: 04-02-2021, Published online: 19-03-2021
}

doi: www.doi.org/10.14202/vetworld.2021.678-688 How to cite this article: Ibrahim NNN, Nasir NM, Sahrani FK, Ahmad A, Sairi F (2021) Characterization of putative pathogenic Shewanella algae isolated from ballast water, Veterinary World, 14(3):678-688.

\begin{abstract}
Background and Aim: Shewanella algae is ubiquitous in marine-associated environments and has been increasingly recognized as a significant human pathogen that can cause serious infections mainly associated with exposure to seawater and ingestion of raw seafood. This study aimed to isolate and characterize $S$. algae from ballast water of ships berthed at Port Klang, Malaysia.

Materials and Methods: Ballast water was sampled from nine ships docked at Port Klang, Malaysia. The isolates were identified and characterized based on biochemical and enzymatic properties, $16 \mathrm{~S} r R N A$ and gyrB sequencing, biofilm formation capability, and antibiotic susceptibility.

Results: A total of four S. algae isolates were isolated from four ballast water samples tentatively name Sa-BW1, Sa-BW2, $\mathrm{Sa}-\mathrm{BW7}$, and Sa-BW8. All isolates showed positive reaction for cytochrome oxidase, catalase, high tolerance to $\mathrm{NaCl}$ $\left(6 \%\right.$ and $8 \%$ ), ability to grow at $42^{\circ} \mathrm{C}$, and on Salmonella-Shigella agar. The strains also exhibited $\beta$-hemolytic activity on sheep blood and human blood agar, positive reaction for lipase, protease, DNase and gelatinase, strong biofilm adherence capabilities and multiple antibiotic resistances against ampicillin, carbenicillin, cephalothin, colistin, novobiocin, oxacillin, penicillin, rifampicin, and tobramycin which suggested their potential pathogenicity.
\end{abstract}

Conclusion: This study demonstrated the occurrence of putative pathogen $S$. algae in ballast water of ships docked at Malaysian port.

Keywords: ballast water, extracellular enzymes, putative pathogen, Shewanella algae.

\section{Introduction}

Ships carry ballast water to control their stability and trim at the start of the voyage. However, the discharge of ballast water near ports risks the transport of invasive species, including pathogenic species from one continent to another. Should a novel genotype of pathogenic species arrived in ballast water, it may establish and persist in the local waters [1] which may lead to the emergence of new virulence strains in the existing population. The global distribution of pathogenic bacteria implicates a negative effect on the existing ecosystem as well as marine animal and human health. The concern about the transmission of potentially pathogenic bacteria through ballast water began in 1992, when the Centers for Disease Control and Prevention of the USA detected Vibrio cholerae in shellfish collected from ballast tanks of cargo ships

Copyright: Ibrahim, et al. Open Access. This article is distributed under the terms of the Creative Commons Attribution 4.0 International License (http://creativecommons.org/licenses/ by/4.0/), which permits unrestricted use, distribution, and reproduction in any medium, provided you give appropriate credit to the original author(s) and the source, provide a link to the Creative Commons license, and indicate if changes were made. The Creative Commons Public Domain Dedication waiver (http:// creativecommons.org/publicdomain/zero/1.0/) applies to the data made available in this article, unless otherwise stated. that had come from South America [2]. Since then, the list of pathogenic species detected in ballast water has increased, including Listeria monocytogenes, Mycobacterium spp., several species of Aeromonas, Pseudomonas, Vibrio, Staphylococcus, the coral pathogens Serratia marcescens, and Sphingomonas spp. and some emerging opportunistic pathogen such as Stenotrophomonas maltophilia and Shewanella algae [3-5]. However, no discharge limits have been set for these pathogens.

Shewanella spp. is ubiquitous in marine-associated environments and widely spread in nature throughout the world. It is a facultative anaerobe, motile, and Gram-negative bacillus belonging to the family Shewanellaceae, order Alteromonadales. The physiological diversity and broad respiratory versatility of Shewanella spp. make it a highly adaptable organism that can survive in different environmental niches. In the previous studies, Shewanella spp. has been isolated from a wide range of environment including freshwater [6], estuary [7], deep sea [8], oil field [9], muddy sediment [10], fish [11], and marine sponge [12]. While members of this genus have been intensively studied for their role in bioremediation [13] and application in microbial fuel cells [14], several 
species have been reported as emerging pathogens in human and aquatic animals. Out of more than 60 known Shewanella species, Shewanella putrefaciens, Shewanella haliotis, Shewanella xiamenensis, and $S$. algae have been documented with pathogenicity in human beings [15-17]. Although human infection by these species is rare, increasing number of cases has been reported worldwide with $>80 \%$ of clinical Shewanella isolates being attributed to the $S$. algae species. [18].

$S$. algae has been recognized as a conditionally pathogenic bacteria to human and aquatic animals $[19,20]$. The most common clinical symptoms described in human infections by $S$. algae are bacteremia, cellulitis, and chronic otitis media [18]. Rare cases of necrotizing soft-tissue infection [21], rupture of aortic aneurysm [22], peritonitis [23], and endocarditis was reported by Davidson et al. [24]. As for aquatic species, S. algae has been identified as a causative agent of ulcer disease for marine fish species, Scinenops ocellata and abalone, Haliotis diversicolor $[11,25]$. Other studies showed that $S$. algae can cause black spot disease to farmed freshwater shrimp, Penaeus vannamei and lesion in reared tonguefish, and Cynoglossus semilaevis $[19,26]$. The pathogenic potential of Shewanella has been controversial as most cases of human infection develop in people with underlying comorbidities and occurred as polymicrobial infections [18,27]. However, prior reports of monomicrobial infection with $S$. algae have suggested the organism as causal in many cases, confirming its ability to cause disease [28-30]. Although infection in healthy hosts is uncommon, rare cases have been reported in individuals with no underlying diseases due to massive exposure to marine environment and seafood consumption [31-33]. The increased in $S$. algae virulence was attributed to its hemolytic activity, enzymatic activity, and biofilm formation $[18,34,35]$.

This study aimed to characterize $S$. algae strains isolated from ships' ballast water incoming to Port Klang, Malaysia. The characterizations were carried out based on the biochemical and enzymatic properties, $16 S$ rRNA and gyrB gene sequence analysis, biofilm formation ability, and susceptibility to antibiotics.

\section{Materials and Methods}

\section{Ethical approval and Informed consent}

No ethical approval was required in this study. The sheep blood for preparation of sheep blood agar was kindly provided by UKM Animal House. The handling and collection of sheep blood were conducted by an assistant veterinary officer. While for human blood agar preparation, human blood samples were collected from healthy volunteers by a medical laboratory technician of the UKM Health Center. Informed consent was obtained from the volunteers included in the study. There was no direct involvement during the blood withdrawal procedures and no further experiments were performed on the subjected animal and human.

\section{Study period and location}

This study was conducted from August 2016 to March 2017 in Port Klang, Malaysia, where ballast water samples were taken from several ships calling at Port Klang.

\section{Sample collection}

Ballast water samples were taken from nine ballast tanks of nine-unit ships docked at Port Klang, Malaysia. The samples were collected using $20 \mathrm{~L}$ bucket through the manhole or overflow pipe when manhole was inaccessible which later filled into $1 \mathrm{~L}$ sterilized Schott bottle. Seawater samples were also taken from four sampling points of surrounding port water using Niskin water sampler. The samples were then transferred back to the laboratory in an icebox for further microbiological analysis. Details of each ballast water samples are shown in Table-1.

\section{Isolation and selection of Shewanella spp.}

The water samples were serially diluted up to $10^{-5}$ using $0.8 \%$ saline water and $0.1 \mathrm{~mL}$ of the diluted samples were inoculated on marine agar by spread plate technique. The plates were incubated at $30^{\circ} \mathrm{C}$ for 3 days. Different colonies were picked and purified by subculturing on marine agar for several times. Pure colonies with distinct morphologies were tested for the following key characteristics of Shewanella, according to the description by Holt and Bruun [18]: Gram stain, motility, cytochrome oxidase, catalase reaction $\left(3 \% \mathrm{H}_{2} \mathrm{O}_{2}\right)$, and $\mathrm{H}_{2} \mathrm{~S}$ production using sulfide indole motility medium. Colonies that fit the description of being Gram-negative bacillus, oxidase-catalase positive, and $\mathrm{H}_{2} \mathrm{~S}$ producing were subjected to further tests.

\section{Biochemical and enzymatic activities}

All presumptive Shewanella isolates were tested for: Utilization of glucose, sucrose, lactose, maltose and citrate, IMViC test (indole, Methyl red, VogesProskauer and citrate) nitrate reduction, growth at $4{ }^{\circ} \mathrm{C}$ and $42{ }^{\circ} \mathrm{C}$, growth in $6 \%$ and $8 \% \mathrm{NaCl}$, and growth on Salmonella-Shigella (SS) agar and MacConkey agar. The following enzymatic activities were also determined: Lipase, protease, DNase, and gelatinase

Table-1: Details of ballast water sampling.

\begin{tabular}{|c|c|c|c|}
\hline $\begin{array}{l}\text { Sample } \\
\text { No. }\end{array}$ & Type of vessel & $\begin{array}{l}\text { BW source/Port } \\
\text { of origin }\end{array}$ & $\begin{array}{l}\text { Location of } \\
\text { sampling }\end{array}$ \\
\hline BW1 & Container ship & Singapore & Manhole \\
\hline BW2 & Container ship & Yokkaichi & Manhole \\
\hline BW3 & Container ship & Mundra & $\begin{array}{l}\text { Sounding } \\
\text { pipe }\end{array}$ \\
\hline BW4 & Container ship & Hong Kong & Manhole \\
\hline BW5 & Container ship & Ning Bo & Manhole \\
\hline BW6 & Container ship & Mormugao & Manhole \\
\hline BW7 & Container ship & Nhava Sheva & Manhole \\
\hline BW8 & Bulk carrier & Malacca strait & Manhole \\
\hline BW9 & Bulk carrier & Zhang Jia Gang & Manhole \\
\hline
\end{tabular}

Veterinary World, EISSN: 2231-0916 
which were performed on spirit blue agar, skim milk agar, DNase agar, and gelatine medium, respectively. Hemolytic activity was determined by streaking the strains on heart infusion agar supplemented with $5 \%$ washed erythrocytes of human and sheep blood. The incubation was performed at $30^{\circ} \mathrm{C}$ for up to $72 \mathrm{~h}$ and the results were recorded.

\section{Confirmation of S. algae by $16 S$ rRNA and gyrB gene sequencing}

Total genomic DNA of the presumptive $S$. algae isolates was extracted using $\mathrm{CTAB} / \mathrm{NaCl}$ method [36]. The $16 S$ rRNA gene was amplified using universal primer, 27F (5'-AGAGTTTGATCCTGGCTCAG-3') and $1492 \mathrm{R}$ (5'-TACGGCTACCTTGTTACG ACTT-3') [37]. A $25 \mu \mathrm{L}$ polymerase chain reaction (PCR) mixture was prepared which consist of $1 \mu \mathrm{L}$ genomic DNA, $12.5 \mu \mathrm{L} 2 \times$ PCR Master Dye Mix, $1 \mu \mathrm{L}(0.1 \mu \mathrm{M})$ primer and $9.5 \mu \mathrm{L}$ sterile distilled water. The PCR conditions were as follows: Initial denaturation at $94^{\circ} \mathrm{C}$ for $5 \mathrm{~min}$, followed by 30 cycles of $94^{\circ} \mathrm{C}$ for $1 \mathrm{~min}, 55^{\circ} \mathrm{C}$ for $1 \mathrm{~min}$, and $72^{\circ} \mathrm{C}$ for 2 min, with a final extension at $72^{\circ} \mathrm{C}$ for $10 \mathrm{~min}$.

Amplification of $g y r B$ gene was carried out using two degenerated primers, UP1 (5'GAA GTCATCATGACCGTTCTGCAYGC NGGNGGNAARTTY GA-3') and UP2R (5'-AGC AGGGTACGATGTGCGAGCCRTCNACRTCN GCRTCNGTCAT-3') with the following conditions: Initial denaturation at $94^{\circ} \mathrm{C}$ for $1 \mathrm{~min}$, followed by 30 cycles of denaturation at $94^{\circ} \mathrm{C}$ for $1 \mathrm{~min}$, primer annealing at $60^{\circ} \mathrm{C}$ for $1 \mathrm{~min}$, primer extension at $72^{\circ} \mathrm{C}$ for $2 \mathrm{~min}$, and final extension at $72^{\circ} \mathrm{C}$ for $7 \mathrm{~min}$ [38].

Sequencing of the $16 \mathrm{~S} r R N A$ and gyrB amplicons was completed by a sequencing company (Apical Scientific Sdn Bhd, Selangor, Malaysia). The obtained sequence data were aligned and analyzed using BioEdit Version 7.0. Species identification was performed by Basic Local Alignment Search Tool (BLAST) (http://blast.ncbi.nlm.nih.gov/Blast.cgi).

\section{Phylogenetic analysis}

The phylogenetic relationship of $S$. algae was determined by comparing the obtained $16 S$ rRNA and gyr $B$ gene sequences with highly identical existing sequences in GenBank database using the BLAST algorithm. Sequences of other Shewanella species were also collected as comparison to the $S$. algae. The multiple alignment and construction of neighbour-joining (NJ) and maximum likelihood (ML) phylogenetic trees were performed using MEGA Version 6.0 [39]. The topology of the phylogenetic tree was evaluated by a bootstrap analysis through 1000 replications. Escherichia coli was used as an outgroup.

\section{Biofilm formation potential test}

The ability of $S$. algae isolates to form biofilm was tested based on microtiter dish biofilm formation assay adapted from O'Toole [40]. The biofilm formation by the isolates was quantified based on the absorbance (OD) reading at $595 \mathrm{~nm}$. Negative control wells contained only marine broth were added in the assay, while suspension of Staphylococcus aureus from UKM Biotechnology and Marine Microbiology Laboratory culture collection was included as positive control. The adherence capabilities of the isolates were classified according to Stepanović et al. [41]. The cutoff $\mathrm{OD}\left(\mathrm{OD}_{\mathrm{C}}\right)$ was defined as three standard deviations above the mean OD of the negative control. In this study, the OD mean of the negative control was $0.083 \pm 0.02$. Hence, the cutoff $\mathrm{OD}\left(\mathrm{OD}_{\mathrm{C}}\right)$ applied in this study was set as 0.143 . Comparing the OD means of isolates well to $\mathrm{OD}_{\mathrm{c}}=0.143,2 \times \mathrm{OD}_{\mathrm{c}}=0.286$ and $4 \times \mathrm{OD}_{\mathrm{C}}=0.332$, the strains were then categorized as follows:

1. $\mathrm{OD} \leq \mathrm{OD}_{\mathrm{C}}=$ Non adherent

2. $\mathrm{OD}_{\mathrm{C}}<\mathrm{OD} \leq 2 \times \mathrm{OD}_{\mathrm{C}}=$ Weakly adherent

3. $2 \times \mathrm{OD}_{\mathrm{C}}<\mathrm{OD} \leq 4 \times \mathrm{OD}_{\mathrm{C}}=$ Moderately adherent 4. $4 \times \mathrm{OD}_{\mathrm{C}}<\mathrm{OD}=$ Strongly adherent

\section{Antibiotic susceptibility test}

Susceptibility of $S$. algae isolates to antibiotics was determined by Kirby-Bauer disk-diffusion technique on Mueller-Hinton agar following protocol by Hudzicki [42] using broad spectrum antibiotics used to treat variety of bacterial infections. The disks used were ampicillin $(20 \mu \mathrm{g})$, carbenicillin $(100 \mu \mathrm{g})$, cephalothin $(30 \mu \mathrm{g})$, chloramphenicol $(30 \mu \mathrm{g})$, ciprofloxacin $(10 \mu \mathrm{g})$, colistin $(10 \mu \mathrm{g})$, gentamicin $(10 \mu \mathrm{g})$, kanamycin $(30 \mu \mathrm{g})$, novobiocin $(30 \mu \mathrm{g})$, oxacillin $(5 \mu \mathrm{g})$, oxytetracycline $(30 \mu \mathrm{g})$, penicillin $(10 \mu \mathrm{g})$, rifampicin $(5 \mu \mathrm{g})$, streptomycin $(25 \mu \mathrm{g})$, and tobramycin $(10 \mu \mathrm{g})$. The diameter of inhibition zone around each antibiotic disk was measured to the nearest millimeter. The zone diameters of each drug were interpreted using the criteria published by the Clinical and Laboratory Standards Institute. The strains were classified as susceptible (S), resistant (R), and intermediate (I) depending on the size of zone inhibition. Multiple antibiotic resistance (MAR) index was calculated as ratio of the number of antibiotics to which the test isolate depicted resistance to the total number of antibiotics to which the test isolate had been evaluated for susceptibility [43]. The MAR index was used as a tool to assess the risk of the isolates coming from a region of high or low antibiotic use. A MAR index $>0.2$ indicates a "high-risk" source of contamination.

\section{Results}

\section{Characterization and identification of S. algae}

A total of 102 isolates were successfully isolated from ballast water. Four of the isolates were presumed as Shewanella species, namely, Sa-BW1, Sa-BW2, Sa-BW7, and Sa-BW8. As for seawater samples, out of 212 isolates that were isolated two of them were presumed as Shewanella, namely, Sa-SW2 and Sa-SW3. The presumptive Shewanella isolates presented as Gram-negative rods and displayed positive reaction for oxidase-catalase test and production of $\mathrm{H}_{2} \mathrm{~S}$. All isolates appeared as circular orange colonies on marine agar. Further biochemical tests revealed 
that all the presumptive Shewanella spp. isolates were tolerant to high $\mathrm{NaCl}$ concentration $(6 \%$, and $8 \%)$ and able to grow at $42^{\circ} \mathrm{C}$ but not at $4{ }^{\circ} \mathrm{C}$. Negative reactions were observed for indole, methyl-red, VogesProskauer, and citrate tests. All strains reduced nitrate to nitrite and produced acid from glucose but not from sucrose, maltose, and lactose. The isolates also grew well on MacConkey and SS agar. Positive enzymatic activities for lipase, protease, DNase, and gelatinase were detected from all strains. They also exhibited a clear zone of beta hemolysis on sheep blood and human blood agar after $48 \mathrm{~h}$ incubation.

Comparison of the biochemical and enzymatic profiles displayed by the presumptive Shewanella isolates with other Shewanella type strains $(S$. algae IAM 14159, S. putrefaciens ATCC 8071, and S. haliotis JCM 14758), as shown in Table-2, suggested all strains as $S$. algae. Further identification by $16 S r R N A$ and gyrB gene sequencing confirmed the identity of the ballast water and seawater isolates. Nucleotide BLAST search of each strain showed $>99 \%$ identity score to existing $S$. algae sequences in database. Sequence data of $S$. algae isolates of ballast water samples from this study were registered in GenBank under accession numbers: $S$. algae strain BW1 (16S; MN548355, gyrB; MN555561), S. algae strain BW2 (16S; MN548356, gyrB; MN555562), S. algae strain
BW7 (16S; MN548357, gyrB; MN555563), and $S$. algae BW1 (16S; MN548358, gyrB; MN555564).

\section{Phylogenetic analysis}

Approximately 1400 bp nucleotide sequences of $16 \mathrm{~S} r R N A$ gene and $1100 \mathrm{bp}$ nucleotide sequences of gyrB genes of $S$. algae ballast water isolates were used for phylogenetic analyses. GenBank nucleotide accession numbers for the $16 S$ rRNA and gyrB gene sequences are shown in the phylogenetic tree. A NJ phylogenetic tree based on 16S rRNA (Figure-1a) indicated that the isolates fell within the clade comprising the members of genus Shewanella, forming a cluster with $S$. algae strain ATCC 51192 with sequences similarities of $99.4 \%$ (Sa-BW1), $99.9 \%$ (Sa-BW2), $99.8 \%$ (Sa-BW7), and $100 \%$ (Sa-BW8). The tree also revealed a very close phylogenetic relationship of the isolates with Shewanella upenei 20-23R with a same sequence similarities values as in S. algae ATCC 51192. The maximum-likelihood tree of $16 S \mathrm{rRNA}$ gene (Figure-1b) showed almost the same topology except for the location of the nearest neighbor, $S$. haliotis DW01 which being clustered together with ballast water isolates, S. algae and S. upenei. The isolates shared sequences similarities of $98.9 \%$ (SA-BW1) and 99.2\% (Sa-BW2, Sa-BW7, and Sa-BW8), to S. haliotis DW01 and 92.8-98.7\% similarities to the other Shewanella species used in the phylogenetic analysis.

Table-2: Biochemical and enzymatic profiles of $S$. algae strains from ballast water.

\begin{tabular}{|c|c|c|c|c|}
\hline Strain/Characteristics & S. algae (Sa-BW) & S. algae IAM $14159^{\top}$ & $\begin{array}{l}\text { S. putrefaciens } \\
{\text { ATCC } 8071^{\top}}^{\text {AT }}\end{array}$ & $\begin{array}{c}\text { S. haliotis JCM } \\
14758^{\top}\end{array}$ \\
\hline \multicolumn{5}{|l|}{ Morphological characteristics } \\
\hline Gram stain & - & - & - & - \\
\hline Cell shape & rod & rod & rod & rod \\
\hline Motility & + & + & + & + \\
\hline Spores & - & - & - & - \\
\hline \multicolumn{5}{|l|}{ Biochemical characteristics } \\
\hline Oxidase & + & + & + & + \\
\hline Catalase & + & NA & + & + \\
\hline Voges-Proskauer & - & NA & NA & NA \\
\hline Methyl red & - & NA & NA & NA \\
\hline Indole production & - & NA & - & - \\
\hline $\mathrm{H} 2 \mathrm{~S}$ production & + & + & + & + \\
\hline Nitrate reduction & + & + & + & + \\
\hline Utilization of glucose & + & + & + & - \\
\hline Utilization of sucrose & - & - & - & - \\
\hline Utilization of lactose & - & - & - & - \\
\hline Utilization of maltose & - & - & - & - \\
\hline Utilization of citrate & - & - & - & + \\
\hline Growth on SS agar & + & + & - & NA \\
\hline Growth on MacConkey & + & NA & NA & NA \\
\hline Growth at $42^{\circ} \mathrm{C}$ & + & + & - & + \\
\hline Growth at $4^{\circ} \mathrm{C}$ & - & - & + & - \\
\hline Growth in $6 \% \mathrm{NaCl}$ & + & + & - & + \\
\hline Growth in $8 \% \mathrm{NaCl}$ & + & NA & NA & + \\
\hline \multicolumn{5}{|l|}{ Enzymatic characteristics: } \\
\hline Lipase & + & + & + & - \\
\hline Protease & + & NA & + & + \\
\hline DNase & + & + & + & + \\
\hline Gelatinase & + & + & NA & + \\
\hline Hemolysis (sheep blood) & + & + & - & NA \\
\hline Hemolysis (human blood) & + & NA & NA & NA \\
\hline
\end{tabular}

$\mathrm{T}^{\mathrm{T}}$ Type strain, NA=Not available, $+=$ positive reaction, $-=$ negative reaction. $\mathrm{S}$. algae: Shewanella algae 


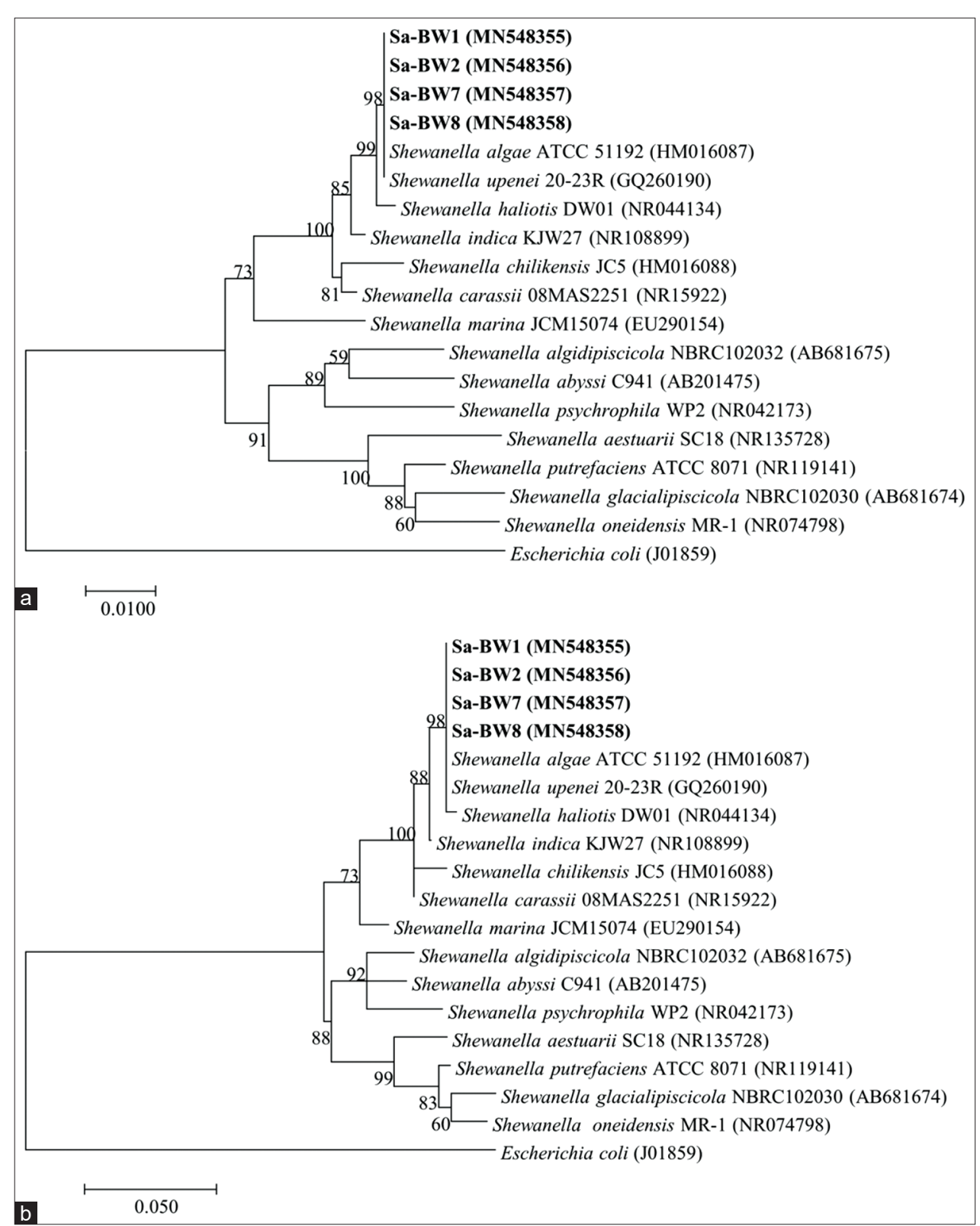

Figure-1: Phylogenetic tree based on $16 S$ rRNA gene sequences of S. algae Sa-BW1, Sa-BW2, Sa-BW7, Sa-BW8, and some other related Shewanella species. (a) Neighbor-joining tree. (b) Maximum-likelihood tree. GenBank accession numbers are given in parentheses.

However, the topology of NJ tree based on the gyrB gene (Figure-2a) showed that these isolates clustered monophyletically, apart from $S$. upenei and $S$. haliotis. The strains showed gyrB gene sequence similarities of $97.7-98.9 \%$ to $S$. upenei, $97.5-97.9 \%$ to S. haliotis, and $73.1-95.2 \%$ to other Shewanella species. Almost the same topology was observed in ML tree of gyrB gene (Figure-2b). Isolates Sa-BW2 and Sa-BW7 formed an independent cluster next to Sa-BW1 indicating that these two isolates have an almost identical sequence to each other with similarity values of $99.5 \%$. Meanwhile, strain Sa-BW8 formed a separated branch which suggests the greater number of sequence difference from the other isolates. Based on phylogenetic analysis and sequence similarity data, strains Sa-BW1, Sa-BW2, Sa-BW7, and Sa-BW8 were clearly regarded as $S$. algae.
Further phylogenetic analysis of $S$. algae gyrB sequences from ballast water isolates against several nearest $S$. algae sequences from GenBank database allows for reasonable interpretation in determining the most likely origin of each isolates from the ballast tank. However, it is impossible to determine the exact origin of the bacteria found in ballast water. Based on the ML tree of gyrB gene generated in Figure-3, isolate Sa-BW1 which ballast water source was from Singapore port was closely related to $S$. algae strains RQs-106 from China. Isolate Sa-BW2 and Sa-BW7 isolates with source of ballast water from Yokkaichi port and Nhava Sheva port, respectively, were clustered together with $S$. algae strain KC-Na-R1 from South Korea. Meanwhile, isolate Sa-BW8 which sourced from Malacca Straits formed a separated branch closely related to strain 2NE11 from Peru. This 


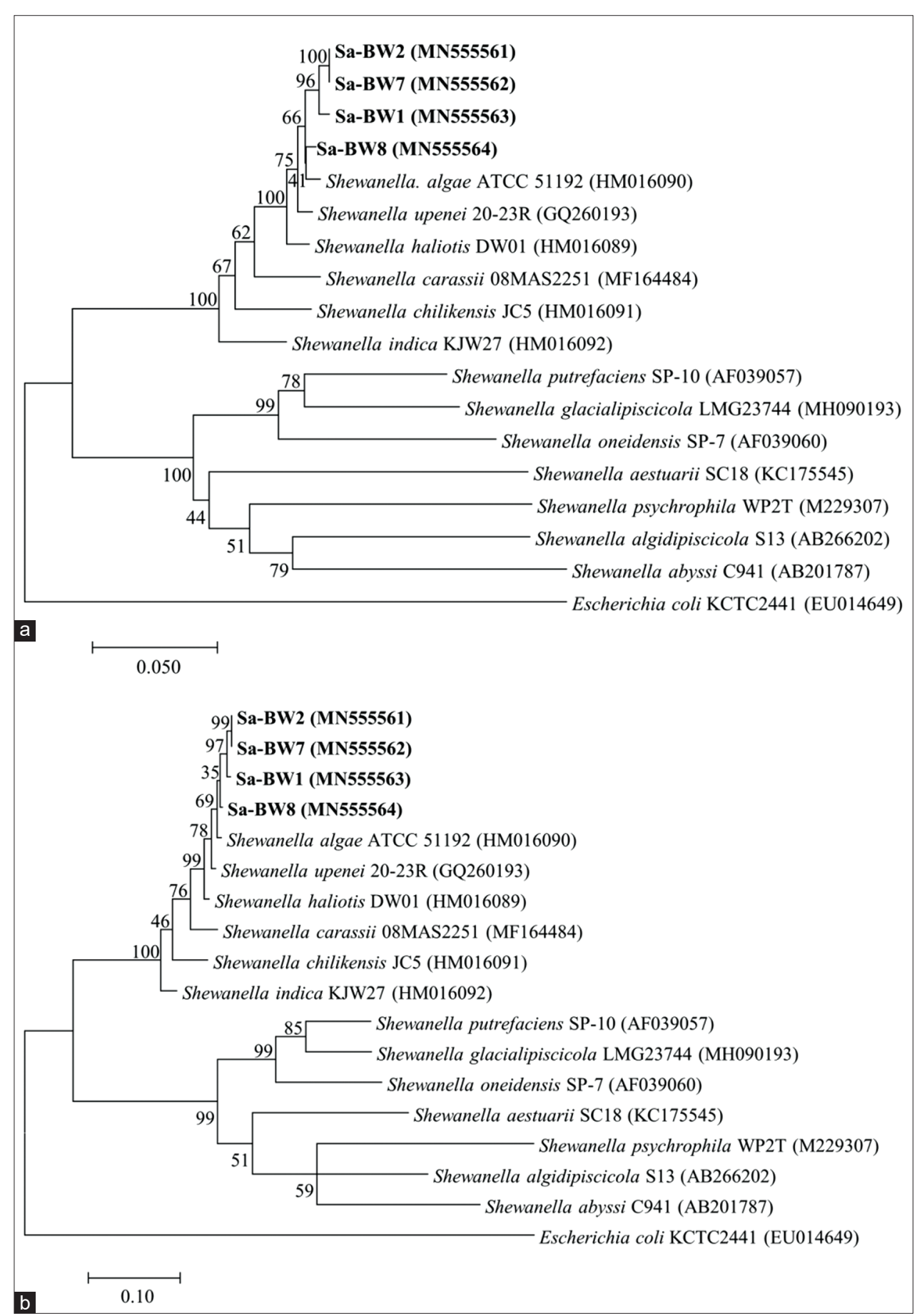

Figure-2: Phylogenetic tree based on gyrB gene sequences of S. algae Sa-BW1, Sa-BW2, Sa-BW7, Sa-BW8, and some other related Shewanella species. (a) Neighbor-joining tree. (b) Maximum-likelihood tree. GenBank accession numbers are given in parentheses.

result suggests that ballast water could transport bacterial species from various regions around the globe contributing to the global spread of the species.

\section{Biofilm formation capabilities}

In this study, the cutoff $\mathrm{OD}_{\mathrm{C}}$ was set as 0.143 . The isolates that showed OD value lesser than 0.143 were considered as non-biofilm former while isolates with $\mathrm{OD}$ value more than $4 \times \mathrm{OD}_{\mathrm{C}}$ were regarded as strong biofilm former. Comparing the OD means of each $S$. algae isolate to differentiation criterion; $\mathrm{OD}_{\mathrm{c}}=0.143,2 \times \mathrm{OD}_{\mathrm{c}}=0.286$, and
$4 \times \mathrm{OD}_{\mathrm{C}}=0.332$, all strains were observed to be strongly adherent with OD value; $1.31 \pm 0.9$ (SaBW1), $1.23 \pm 1.0$ (Sa-BW2), $1.16 \pm 0.5$ (Sa-BW7), $0.91 \pm 0.4$ (Sa-BW8), $0.93 \pm 0.01 \quad$ (Sa-SW2), and $0.89 \pm 0.6$ (Sa-SW3), respectively. Positive control, $S$. aureus showed OD value $0.92 \pm 0.05$ indicated strong adherence capabilities.

\section{Antibiotic susceptibility}

A similar pattern of antibiotic susceptibility was observed in all $S$. algae strains. As summarized in Table-3, multiple resistance was observed against 


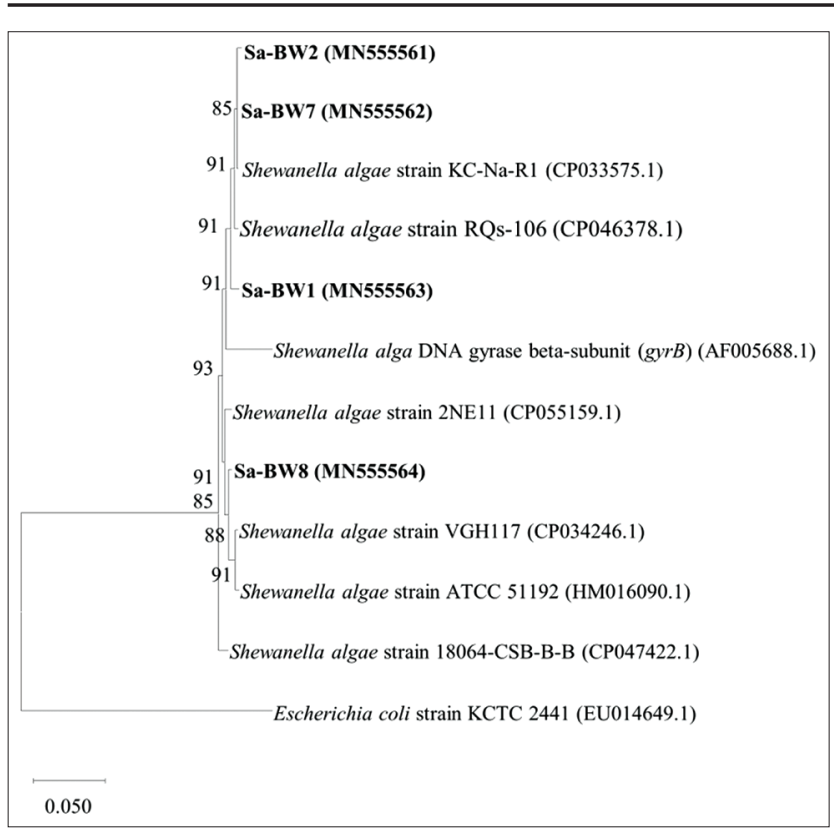

Figure-3: Maximum likelihood phylogenetic tree based on gyrB gene sequences of Shewanella algae Sa-BW1, Sa-BW2, Sa-BW7, Sa-BW8, and some other closely related S. algae strains. GenBank accession numbers are given in parentheses.

Table-3: Antibiotic resistance profile of $S$. algae strains from ballast water.

\begin{tabular}{lcc}
\hline Antibiotics & Disc content $(\boldsymbol{\mu g})$ & Sensitivity \\
\hline Ampicillin & 20 & $\mathrm{R}$ \\
Carbenicillin & 100 & $\mathrm{R}$ \\
Cephalothin & 30 & $\mathrm{R}$ \\
Ciprofloxacin & 10 & $\mathrm{~S}$ \\
Chloramphenicol & 30 & $\mathrm{~S}$ \\
Colistin & 10 & $\mathrm{R}$ \\
Gentamicin & 10 & $\mathrm{~S}$ \\
Kanamycin & 30 & $\mathrm{I}$ \\
Novobiocin & 30 & $\mathrm{R}$ \\
Oxacillin & 5 & $\mathrm{R}$ \\
Oxytetracycline & 30 & $\mathrm{I}$ \\
Penicillin & 10 & $\mathrm{R}$ \\
Rifampicin & 5 & $\mathrm{R}$ \\
Streptomycin & 25 & $\mathrm{I}$ \\
Tobramycin & 10 & $\mathrm{R}$ \\
MAR index $(\mathrm{a} / \mathrm{b})$ & & 0.6 \\
\hline
\end{tabular}

$\mathrm{S}=$ Susceptible, I = Intermediate, $\mathrm{R}=$ Resistance, $\mathrm{a} / \mathrm{b}=$ calculation ratio. S. algae: Shewanella algae

oxacillin, ampicillin, carbenicillin, cephalothin, novobiocin, tobramycin, colistin, and rifampicin. Intermediate resistance to kanamycin, oxytetracycline, and streptomycin was also recorded. The isolates were only sensitive to ciprofloxacin, chloramphenicol and gentamicin. The MAR index recorded was $>0.2$ suggesting that the isolates were originated from a source that has antibiotic contamination [43].

\section{Discussion}

In this study four $S$. algae was isolated from ballast water of ships docked in Port Klang, Malaysia. The isolates had key phenotypic characteristics of oxidase positive and sulfide production attributed to Shewanella spp. [18]. Additional phenotypic characteristics such as the ability to grow at $42^{\circ} \mathrm{C}$, tolerance to high salt concentration (6-8\%), and hemolysis on sheep blood agar distinguished the $S$. algae isolates from other species such as $S$. putrefaciens, $S$. haliotis and $S$. xiamenensis as described in the previous study [44]. These characteristics grouped the $S$. algae isolates into mesophilic and halophilic Shewanella strains as reported by several studies [45-47]. The biochemical characteristics of $S$. algae isolate from this study were similar to $S$. algae from the first Danish cases of $S$. algae bacteremia [48], shrimp (P. vanna$m e i)$ [26], and type strain IAM 14159 [49]. Previous study by Altug et al. [4] also reported the presence of $S$. algae in several ballast water samples collected from ships berthed around Ambali Port, on the northern shores of Sea of Marmara.

The presence of $S$. algae in both ballast water and port water samples raises the possibility that some species may have been transported there through ballast water. Whether this species was introduced or is native and common in the local port water remains an open question. Since bacterial species may also be introduced to every marine environment in many ways and may be present in polluted environment, we cannot clearly conclude that the presence of $S$. algae in the local water is due to the release of ballast water. However, suppose the ballast water that contains the S. algae were released during cargo loading, the species will be transferred to local port water. The same goes to the species present in local water during unloading cargo process where ballasting procedure could transport the species into ballast tank to another port of call. These scenarios would validate the ballast water potential as a vector for global spread of microorganisms.

The phylogenetic analysis grouped the strains (Sa-BW1, Sa-BW2, Sa-BW7, and Sa-BW8) in the $S$. algae cluster, closest to $S$. algae ATCC 51192. Based on the comparative analysis of phylogenetic tree, the $\operatorname{gyr} B$ gene seems to be more reliable and useful than $16 S$ rRNA for describing phylogenetic relationship at the species level. The $S$. algae isolates showed independent branching from $S$. haliotis and $S$. upenei based on $\operatorname{gyr} B$ gene with similarities values of $97.0-97.9 \%$ and $97.7-98.5 \%$, respectively, which were much lower than in $16 S$ rRNA (>99\%). The lower occurrences of interspecies sequence similarities in $g y r B$ gene compared to $16 S r R N A$ described in this study implied a better resolution to distinguish $S$. algae isolates from its closely related species, $S$. haliotis and $S$. upenei. It is known that the rate of molecular evolution of gyrB sequences is faster than 16S rRNA which provides higher phylogenetic resolution. It was reported in several studies that $g y r B$ gene has always been used as a discriminative detection for Shewanella species identification [50-52]. The similarities values of greater than $97 \%$ observed in both gyrB and $16 S$ rRNA sequences of $S$. algae isolates with $S$. haliotis and $S$. upenei revealed a very close 
phylogenetic association between the three species. This might also indicate a potential taxonomic problem in the presumptive identification of this related strain. However, in recent whole-genome sequencing $S$. haliotis and $S$. upenei were proposed as a later heterotrophic synonym of $S$. algae [53-55]. The phylogenetic analysis of gyrB gene sequence between S. algae isolates from ballast water and nearest $S$. algae strains sequences from GenBank database revealed the phylogenetically relatedness of the ballast water strain with $S$. algae strains from various region around the globe. The fact that the $S$. algae isolates from this study itself were isolated from ballast tanks of different ballast water sources (port of origin) would validate the role of ballast water in transporting the bacterial species around the world, contributing to the global spread. It can be difficult and almost impossible to track the exact origin of the bacterial species as ballast water exchange can be made at different ports [3]. In addition, the ballast tank can contain mixture of water from different ports because there is always a small portion of unpumpable water that remains before taking on cargo.

The capability of all S. algae isolates in this study to produce extracellular enzymes such as lipase, protease, DNase, and hemolysin could be inferred as part of adaptive mechanism for the species to survive in their respective marine environment. The expression of this phenotype could be aimed at reducing surrounding microbial competition or degrading organic matter to gain access to their nutrients $[20,56]$. However, the adaptation allowing survival in marine environment could also allow for colonization of living hosts if the bacteria get the opportunity to enter the host. These enzymes which are known to have pathogenic potential are capable of enhancing bacterial virulence as they enable the bacteria to breach and invade host tissue contributing to a wide range of infections [57-59]. According to Edberg et al. [60], no single extracellular enzyme has been proved to be the sole factor responsible for bacterial pathogenicity. Thus, it is considered necessary for microbes to contain more than one extracellular enzyme to be virulent. In general, hemolytic activity has been considered as an important virulence marker for Shewanella spp. to predict potentially virulent strain [61-63]. In a mouse pathogenicity study performed by Khashe and Janda [34], $S$. algae was observed to be the more virulent species compared to $S$. putrefaciens, and it was speculated that hemolytic activity could play an important virulence factor. Thus, the ability of $S$. algae isolates in this study to exhibit beta-hemolytic activity on sheep blood and human blood agar suggested their potential as putative pathogen.

The ability of $S$. algae isolates to form a strong biofilm formation, as shown in this study suggested a significant advantage for the survival adaptation of this species in ballast tank. The production of exopolysaccharides matrix in the formation of biofilms could provide protection from mechanical or chemical treatment and from predatory protists [64]. The biofilm environment may also promote phenotypic modification as well as genetic exchanges among the communities of microorganisms within biofilms [65]. Although it has not been tested, antibiotic resistance or virulence in $S$. algae may be enhanced through horizontal gene transfer should a novel genotype or toxigenic species arrive in ballast water. This protective film may act as refuge for bacteria during transport allowing them to persist within the tank environment and proliferate. In term of pathogenicity, formation of biofilms provides protection against immune system and antibiotic treatment thus preventing access of certain antimicrobial agents from reaching the bacterial cells within the biofilm which could complicate the clinical treatment of S. algae [66].

Resistance to antibiotics has been inferred to encourage host pathogenesis allowing persistent or chronic diseases [67]. Studies on antibiotic susceptibility profiles of Shewanella spp. indicated that most species are susceptible to aminoglycosides, carbapenems, erythromycin, quinolones, extended-spectrum cephalosporins, and macrolides, but resistance to penicillin [68-70]. However, there has been an increase in the occurrence of multidrug resistance in $S$. algae strains [71-73] including the isolates from the current study. The most commonly reported antibiotic resistance is against beta-lactams, such as amoxicillin, ampicillin, and penicillin; and against cephalosporins such as cephalothin, cefazolin, and cefotaxime [74] in accordance with the resistance observed in this study. Notably, $S$. algae is frequently reported to be resistant to colistin [73]. Resistance to tobramycin, novobiocin, and rifampicin was also observed in several studies $[24,26,73]$. The multiple resistance profile observed in $S$. algae strains of ballast water are of concern as horizontal gene transfer of antibiotic resistance genes might occur due to the closed system and water retention time within ballast tanks [75].

\section{Conclusion}

In this study, four S. algae strains were isolated from ballast water samples taken from ships docked at Port Klang, Malaysia. The isolates were found to produce hemolytic activity on sheep blood agar, secreted several extracellular enzymes (lipase, protease, DNase, and gelatinase), performed a strongly adherent biofilm and demonstrated multiple resistances toward antibiotics. These characteristics may represent the putative pathogenic factor of the $S$. algae strains. The presence of putative pathogenic strains in ballast water suggested that ships carry a potential risk to local marine environment, should they release the pathogenic strains during ballasting operation. While $S$. algae is already present in Port Klang waters, further introduction of it could pose a risk to the local ecosystem. Hence, monitoring level of pathogenic species should be continued in incoming ballast water 
to protect the local environment from bacteriological risks and to guard the public on possible health risks in port environments.

\section{Authors' Contributions}

NNNI, NMN, and FS designed the study. NNNI and NMN did laboratory analysis and collected data. FKS, FS, and AA reviewed the manuscript. FKS and FS were the supervisors for the study. All authors read and approved the final manuscript.

\section{Acknowledgments}

The authors thank the Universiti Kebangsaan Malaysia for providing equipment and infrastructures for the research. The study was financially supported by the Malaysian Ministry of Science, Technology and Innovation (MOSTI) Science Fund (Grant no.; 04-01-02-SF1244) and Ministry of Higher Education (MOHE) Fundamental Research Grant Scheme (Grant no. FRGS/1/2019/STG05/UKM/02/6).

\section{Competing Interests}

The authors declare that they have no competing interests.

\section{Publisher's Note}

Veterinary World remains neutral with regard to jurisdictional claims in published institutional affiliation.

\section{References}

1. Ruiz, G.M., Rawlings, T.K., Dobbs, F.C., Drake, L.A., Mullady, T., Huq, A. and Colwell, R.R. (2000) Global spread of microorganisms by ships. Nature, 408(6808): 49-50.

2. Mccarthy, S., McPhearson, R.M., Guarino, A. and Gaines, J. (1992) Toxigenic Vibrio cholerae 01 and cargo ships entering Gulf of Mexico. Lancet, 339(8793): 624-625.

3. Aguirre-Macedo, M.L., Vidal-Martinez, V.M., HerreraSilveira, J.A., Valdés-Lozano, D.S., Herrera-Rodríguez, M. and Olvera-Novoa, M.A. (2008) Ballast water as a vector of coral pathogens in the Gulf of Mexico: The case of the Cayo Arcas coral reef. Mar. Pollut. Bull., 56(9): 1570-1577.

4. Altug, G., Gurun, S., Cardak, M., Ciftci, P.S. and Kalkan, S. (2012) The occurrence of pathogenic bacteria in some ships' ballast water incoming from various marine regions to the Sea of Marmara, Turkey. Mar. Environ. Res., 81(2012): 35-42.

5. Brinkmeyer, R. (2016) Diversity of bacteria in ships ballast water as revealed by next generation DNA sequencing. Mar. Pollut. Bull., 107(1): 277-285.

6. El-Barbary, M.I. (2017) First recording of Shewanella putrefaciens in cultured Oreochromis niloticus and its identification by $16 \mathrm{Sr}$ RNA in Egypt. Egypt. J. Aquat. Res., 43(1): 101-107.

7. Skerratt, J.H., Bowman, J.P. and Nichols, P.D. (2002) Shewanella olleyana spp. nov., a marine species isolated from a temperate estuary which produces high levels of polyunsaturated fatty acids Int. J. Syst. Evol. Microbiol., 52(6): 2101-2106.

8. Wang, M. and Sun, L. (2016) Shewanella inventionis spp. nov., isolated from deep-sea sediment. Int. J. Syst. Evol. Microbiol., 66(12): 4947-4953.

9. Semple, K.M. and Westlake, D.W.S. (1987) Characterization of iron-reducing Alteromonas putrefaciens strains from oil field fluids. Can. J. Microbiol., 33(5): 366-371.
10. Baaziz, H., Lemaire, O.N., Jourlin-Castelli, C., IobbiNivol, C., Méjean, V., Alatou, R. and Fons, M. (2018) Draft genome sequence of Shewanella algidipiscicola $\mathrm{H} 1$, a highly chromate-resistant strain isolated from Mediterranean marine sediments. Microbiol. Resour. Announc., 7(8): e00905-18.

11. Chang, C., Chaoqun, H., Xiaoyan, C. and Luping, Z. (2003) Identification and characterization of Shewanella algae as a novel pathogen of ulcer disease of fish Scinenops ocellata. Oceanol. Limnol. Sin., 34(1): 1-8.

12. Yang, S., Kwon, K.K., Lee, H., Kim, S. and Kim, S. (2006) Shewanella spongiae spp. nov., isolated from a marine sponge. Int. J. Syst. Evol. Microbiol., 56(12): 2879-2882.

13. Fredrickson, J.K., Romine, M.F., Beliaev, A.S., Jennifer, M., Osterman, L., Pinchuk, G., Reed, J.L., Rodionov, D.A. and Jorge, L.M. (2008) Towards environmental systems biology of Shewanella. Nat. Rev. Microbiol., 6(8): 592-603.

14. Li, F., Li, Y., Sun, L., Li, X., Yin, C., An, X., Chen, X. and Tian, Y. (2017) Shewanella oneidensis enables xylose-fed microbial fuel cell. Biotechnol. Biofuels., 10(196): 1-10.

15. Zong, Z. (2011) Case report nosocomial peripancreatic infection associated with Shewanella xiamenensis. J. Med. Microbiol., 60(9): 1387-1390.

16. Hochedez, P., Vignier, N., Barreau, M., Olive, C., Baubion, E. and Theodose, R. (2013) Human infection with Shewanella putrefaciens and S. algae: Report of 16 cases in Martinique and review of the literature. Am. J. Trop. Med. Hyg., 89(1): 151-156.

17. Khurshid, A., Shaukat, S., Suleman, R.M. and Angez, M. (2013) Shewanella haliotis associated with severe soft tissue infection, Thailand. Emerg. Infect. Dis., 19(6): 1019-1021.

18. Holt, H.M. and Bruun, B. (2005) Shewanella algae and Shewanella putrefaciens: Clinical and microbiological characteristics. Clin. Microbiol. Infect., 11(5): 347-352.

19. Han, Z., Sun, J., Lv, A., Sung, Y., Shi, H., Hu, X. and Xing, K. (2017) Isolation, identification and characterization of Shewanella algae from reared tongue sole, Cynoglossus semilaevis Günther. Aquaculture, 468(2017): 356-362.

20. Lemaire, O.N., Méjean, V. and Iobbi-Nivol, C. (2020) The Shewanella genus: Ubiquitous organisms sustaining and preserving aquatic ecosystems. FEMS Microbiol. Rev., 44(2): 155-170.

21. Ananth, A.L., Nassiri, N. and Pamoukian, V.N. (2014) Case reports Shewanella algae: A rare cause of necrotizing fasciitis. Surg. Infect., 15(3): 336-338.

22. Paccalin, M., Grollier, G., Le Moal, G., Rayeh, F. and Camiade, C. (2001) Rupture of a primary aortic aneurysm infected with Shewanella alga. Scand. J. Infect. Dis., 33(10): 774-775

23. Shanmuganathan, M., Goh, B.L., Lim, C., NorFadhlina, Z. and Fairol, I. (2016) Shewanella algae peritonitis in patients on peritoneal dialysis. Perit. Dial. Int., 36(5): 574-575.

24. Davidson, N.L., Subedi, S., Wilks, K. and Morgan, J. (2018) A case of Shewanella algae endocarditis: An emerging pathogen with a diverse clinical spectrum. BMJ. Case. Rep., 2018(2018): bcr2017223396

25. Cai, J. and Thompson, K.D. (2006) Isolation and identification of Shewanella alga and its pathogenic effects on post-larvae of abalone Haliotis diversicolor supertexta. $J$. Fish. Dis., 29(8): 505-508.

26. Cao, H., Chen, S., Lu, L., An, J. (2018) Shewanella algae: An emerging pathogen of black spot disease in freshwater-cultured white leg shrimp (Penaeus vannamei). Isr. J. Aquacult. Bamid., 70(1): 1-7.

27. Janda, J.M. and Abbott, S.L. (2012) The genus Shewanella: From the briny depths below to human pathogen. Crit. Rev. Microbiol., 40(4): 293-312.

28. Torri, A., Bertini, S., Schiavone, P., Congestri, F., Matteucci, M., Sparacino, M., Testa, G., Pedna, M.F. and Sambri, V. (2018) Shewanella algae infection in Italy: Report of 3 years' evaluation along coast of the Northern 
Adriatic sea. New Microbes New Infect., 23(2018): 39-43.

29. Dey, S., Bhattacharya, D., Roy, S., Nadgir, S.D., Patil, A. and Kholkute, S.D. (2015) Shewanella algae in acute gastroenteritis. Indian J. Med. Microbiol., 33(1): 172-175.

30. Takata, T., Chikumi, H., Morishita, S., Hamada, S., Hoi, S. and lyama, T. (2017) Shewanella algae bacteremia in an end-stage renal disease patient: A case report and review of the literature. Intern. Med., 56(6): 729-732.

31. Baeur, M.J., Stone-Garza, K.K., Croom, D., Andreoli, C., Woodson, P., Graf, P.C.F. and Maves, R.C. (2019) Shewanella algae infections in United States naval special warfare trainees. Open Forum Infect. Dis., 6(11): ofz442.

32. Martin-Rodriguez, A.J., Martin-Pujol, O., ArtilesCampelo, F., Bolanos-Rivero, M. and Romling, U. (2017) Shewanella spp. infections in Gran Canaria, Spain: Retrospective analysis of 31 cases and a literature review. JMM Case Rep., 4(12): e005131.

33. Fluke, E.C., Carayannopoulos, N.L. and Lindsey, R.W. (2016) Pyogenic flexor tenosynovitis caused by Shewanella algae. J. Hand Surg. Am., 41(7): 1-4.

34. Khashe, S. and Janda, J.M. (1998) Biochemical and pathogenic properties of Shewanella alga and Shewanella putrefaciens. J. Clin. Microbiol., 36(3): 783-787.

35. Srinivas, J., Pillai, M., Vinod, V. and Dinesh, R.K. (2015) Skin and soft tissue infections due to Shewanella algae. An emerging pathogen. J. Clin. Diagn. Res., 9(2): 16-20.

36. Andreou, L.V. (2013) Preparation of genomic DNA from bacteria. Methods. Enzymol., 529: 143-151.

37. Weisburg, W.G., Barns, S.M., Pelletier, D.A. and Lane, D.J. (1991) 16S ribosomal DNA amplification for phylogenetic study. J. Bacteriol., 173(2): 697-703.

38. Yamamoto, S. and Harayama, S. (1995) PCR amplification and direct sequencing of gyrB genes with universal primers and their application to the detection and taxonomic analysis of Pseudomonas putida strains. Appl. Environ. Microbiol., 61(3): 1104-109.

39. Tamura, K., Stecher, G., Peterson, D., Filipski, A. and Kumar, S. (2013) MEGA6: Molecular evolutionary genetics analysis version 6.0. Mol. Biol. Evol., 30(12): 2725-2729.

40. O'Toole, G.A. (2010) Microtiter dish biofilm formation assay. J. Vis. Exp., 47(2011): 10-11.

41. Stepanović, S., Vuković, D., Dakić, I., Savić, B. and Švabić-Vlahović, M. (2000) A modified microtiter-plate test for quantification of staphylococcal biofilm formation. J. Microbiol. Methods, 40(2): 175-179.

42. Hudzicki, J. (2016) Kirby-Bauer Disk Diffusion Susceptibility Test Protocol. Available from: https://www. asm.org/protocols/kirby-bauer-disk-diffusion-susceptibility-test-pro. Retrieved on 29-8-2018

43. Krumperman, P.H. (1983) Multiple antibiotic resistance indexing of Escherichia coli to identify high-risk sources of fecal contamination of foods. Appl. Environ. Microbiol., 46(1): $165-170$

44. Satomi, M. (2013) The family Shewanellaceae. In: Rosenberg,E., editor.TheProkaryotes: Gammaproteobacteria. Springer-Verlag, Berlin, Heidilberg. p597-625.

45. DeFrank, J.J., Beaudry, W.T., Cheng, T.C., Harvey, S.P., Stroup, A.N. and Szafraniec, L.L. (1993) Screening of halophilic bacteria and Alteromonas species for organophosphorus hydrolyzing enzyme activity. Chem. Biol. Interact., 87(1-3): 141-148.

46. Gram, L., Bundvad, A., Melchiorsen, J., Johansen, C. and Vogel, B.F. (1999) Occurrence of Shewanella algae in Danish coastal water and effects of water temperature and culture conditions on its survival. Appl. Environ. Microbiol., 65(9): 3896-3900.

47. Tseng, S.Y., Liu, P.Y., Lee, Y.H., Wu, Z.Y., Huang, C.C., Cheng, C.C. and Tung, K.C. (2018) The pathogenicity of Shewanella algae and ability to tolerate a wide range of temperatures and salinities. Can. J. Infect. Dis. Med. Microbiol., 2018(2018): 6976897.

48. Domínguez, H., Vogel, B.F., Gram, L., Hoffmann, S. and
Schaebel, S. (1996) Shewanella alga bacteremia in two patients with lower leg ulcers. Clin. Infect. Dis., 22(6): 1036-1039.

49. Nozue, H., Hayashi, T., Hashimoto, Y., Ezaki, T., Hamasaki, K., Ohwada, K. and Terawaki, Y. (1992) Isolation and characterization of Shewanella alga from human clinical specimens and emendation of the description of $S$. alga Simidu et al., (1990). Int. J. Syst. Bacteriol., 42(4): 628-634.

50. Satomi, M., Vogel, B.F., Gram, L. and Venkateswaran, K. (2006) Shewanella hafniensis spp. Nov. and Shewanella morhuae spp. Nov., isolated from marine fish of the Baltic Sea. Int. J. Syst. Evol. Microbiol., 56(1): 243-249.

51. Fang, Y., Wang, Y., Liu, Z., Lu, B., Dai, H., Kan, B. and Wang, D. (2017) Shewanella carassii spp. Nov., isolated from surface swabs of crucian carp and faeces of a diarrhoea patient. Int. J. Syst. Evol. Microbiol., 67(12): 5284-5289.

52. Fang, Y., Wang, Y., Liu, Z., Dai, H., Cai, H., Li, Z., Du, Z., Wang, X., Jing, H., Wei, Q., Kan, B. and Wang, D. (2019) Multilocus sequence analysis, a rapid and accurate tool for taxonomic classification, evolutionary relationship determination, and population biology studies of the genus Shewanella. Appl. Environ. Microbiol., 85(11): 1-13.

53. Szeinbaum, N., Kellum, C.E., Glass, J.B., Janda, J.M. and DiChristina, T.J. (2018) Whole-genome sequencing reveals that Shewanella haliotis Kim et al. 2007 can be considered a later heterotypic synonym of Shewanella algae Simidu et al. 1990. Int. J. Syst. Evol. Microbiol., 68(4): 1356-1360.

54. Kim, K.K., Kim, Y.O., Park, S., Kang, S.J., Nam, B.H., Kim, D.N., Oh, T.K. and Yoon, J.H. (2011) Shewanella upenei spp. Nov., a lipolytic bacterium isolated from bensasi goatfish Upeneus bensasi. J. Microbiol., 49(3): 381-386.

55. Simidu, U., Kita-Tsukamoto, K., Yasumoto, T. and Yotsu, M. (1990) Taxonomy of four marine bacterial strains that produce tetrodotoxin. Int. J. Syst. Evol. Microbiol., 40(4): 331-336.

56. Mogrovejo-Arias, D.C., Brill, F.H.H. and Wagner, D. (2020) Potentially pathogenic bacteria isolated from diverse habitats in Spitsbergen, Svalbard. Environ. Earth Sci., 79(109): 1-9.

57. Bottone, E.J., Reitano, M., Janda, J.M., Troy, K. and Cuttner, J. (1986) Pseudomonas maltophilia exoenzyme activity as correlate in pathogenesis of ecthyma gangrenosum. J. Clin. Microbiol., 24(6): 995-997.

58. Tomas, J.M. (2012) The main Aeromonas pathogenic factors. ISRN Microbiol., 2012(2012): 256261.

59. Pavlov, D., De Wet, C.M., Grabow, W.O. and Ehlers, M.M. (2004) Potentially pathogenic features of heterotrophic plate count bacteria isolated from treated and untreated drinking water. Int. J. Food. Microbiol., 92(3): 275-287.

60. Edberg, S.C., Gallo, P. and Kontnick, C. (1996) Analysis of the virulence characteristics of bacteria isolated from bottled, water cooler, and tap water. Microb. Ecol. Health Dis., 9(2): 67-77.

61. Myung, D.S., Jung, Y.S., Kang, S.J., Song, Y.A., Park, K.H., Jung, S.I., Kim, S.H. and Shin, J.H. (2009) Primary Shewanella algae bacteremia mimicking Vibrio septicemia. J. Korean Med. Sci., 24(6): 1192-1194.

62. Tseng, S.Y., Liu, P.Y., Lee, Y.H., Wu, Z.Y., Huang, C.C., Cheng, C.C. and Tung, K.C. (2018) The pathogenicity of Shewanella algae and ability to tolerate a wide range of temperatures and salinities. Can. J. Infect. Dis. Med., 2018(2018): 6976897

63. Richards, G.P., Watson, M.A., Crane, E.J.M., Burt, I.G. and Bushek, D. (2008) Shewanella and Photobacterium spp. in oysters and seawater from the Delaware Bay. Appl. Environ. Microbiol., 74(11): 3323-3327.

64. Drake, L.A., Doblin, M.A. and Dobbs, F.C. (2007) Potential microbial invasion via ships' ballast water, sediment and biofilm. Mar. Pollut. Bull., 55(7-9): 333-341.

65. Drake, L.A., Meyer, A.E., Forsberg, R.L., Baier, R.E., Doblin, M.A., Heinemann, S., Johnson, W.P., Koch, M., Rublee, P.A. and Dobbs, F.C. (2005) Potential invasion of microorganisms and pathogens via "interior hull fouling": 
Biofilms inside ballast water tanks. Biol. Invasions, 7(6): 969-982.

66. Davies, D. (2003) Understanding biofilm resistance to antibacterial agents. Nat. Rev. Drug Discov., 2(2): 114-122.

67. Schroeder, M., Brooks, B.D. and Brooks, A.E. (2017) The complex relationship between virulence and antibiotic resistance. Genes, 8(1): 39.

68. Holt, H.M., Gahrn-Hansen, B. and Bruun, B. (2005) Shewanella algae and Shewanella putrefaciens: Clinical and microbiological characteristics. Clin. Microbiol. Infect., 11(5): 347-352.

69. Janda, J.M. (2014) Shewanella: A marine pathogen as an emerging cause of human disease. Clin. Microbiol. Newsl., 36(4): 25-29.

70. Martín-Rodríguez, A.J., Martín-Pujol, O., ArtilesCampelo, F., Bolaños-Rivero, M. and Römling, U. (2017) Shewanella spp. infections in Gran Canaria, Spain: Retrospective analysis of 31 cases and a literature review. JMM Case Rep., 4(12): 1-9.
71. Bhatawadekar, S.M. and Sharma, J. (2011) Brevundimonas vesicularis bacteremia: A rare case report in a female infant. Indian J. Med. Microbiol., 29(4): 420-422.

72. Jampala, S., Meera, P., Vivek, V. and Kavitha, D.R. (2015) Skin and soft tissue infections due to Shewanella algae an emerging pathogen. J. Clin. Diagn. Res., 9(2): 16-20.

73. Cimmino, T., Olaitan, A.O. and Rolain, J.M. (2016) Wholegenome sequence to decipher the resistome of Shewanella algae, a multidrug-resistant bacterium responsible for pneumonia, Marseille, France. Expert. Rev. Antiinfect. Ther., 14(2): 269-275.

74. Huang, Y.T., Tang, Y.Y., Cheng, J.F., Wu, Z.Y., Mao, Y.C. and Liu, P.Y. (2018) Genome analysis of multidrug-resistant Shewanella algae isolated from human soft tissue sample. Front. Pharmacol., 9(2018): 419.

75. Ng, C., Le, T.H., Goh, S.G., Liang, L., Kim, Y., Rose, J.B. and Yew-Hoong, K.G. (2015) A comparison of microbial water quality and diversity for ballast and tropical harbor waters. PLoS One, 10(11): 1-22. 